\author{
István POMÁZI (D)*, Elemér SZABÓ
}

\title{
CIRCULAR ECONOMY POLICY-RELATED NATIONAL INITIATIVES IN VISEGRAD COUNTRIES
}

\begin{abstract}
The concept of circular economy (CE) has become popular in the last decade: both decision-makers and businesses are looking for alternative solutions replacing the present economic model. Official governmental documents have been selected for introducing Visegrad countries' (V4) initiatives and monitoring the progress toward a transition to a circular economy. Based on selected material flow and resource productivity (RP) indicators, the study compares the regional differences among Visegrad countries. The current performances of the V4 in the implementation of the circular economic model are below the EU average. Moreover, it is noticeable that the dynamics of the changes of each indicator is more positive than on average in the EU, however, only moderate relative decoupling of domestic material (DMC) from GDP has occurred. When comparing individual countries, the wide range of the policy measures taken by V4 countries to support the transition to a circular economy can be considered promising. Despite the different characteristics of Visegrad countries, they show similar performances that are rather close to each other and incrementally approach to the EU average.
\end{abstract}

Key words: circular economy, resource productivity, measuring progress, Visegrad countries.

\section{INTRODUCTION}

The intensity of material use is increasing globally despite the partial dematerialisation of the global economy based on the rationalisation of production and services and info-communication technology. In 2019, according to a recent report, only 8.6 per cent of the world's economy was circular, consuming 100 billion tonnes of materials a year for the first time (Circle Economy, 2020). This may increase up to 190 billion tons a year by 2060 provided that historical trends continue (International Resource Panel, 2019).

\footnotetext{
* István POMÁZI, Eötvös Loránd University, Egyetem tér 1-3., H-1053 Budapest, Hungary; e-mail: pomazi.istvan@gmail.com, ORCID: https://orcid.org/0000-0001-5736-0080

${ }_{* *}^{*}$ Elemér SZABÓ, National Research, Development and Innovation Office, Kéthly Anna tér 1, H-1077 Budapest, Hungary; e-mail: szabelem@gmail.com, ORCID: https://orcid.org/0000-0002-2275-671X
} 
The strategies and action plans adopted to implement a closed-loop product life cycle aim at supporting circular economy (CE) at each stage of the value chain, from production to consumption, from repair to production, including waste management and recycled raw materials.

To make CE widely used, significant changes need to take place along entire value chains, from product design to new business and market models, from new ways of turning waste into secondary materials to new forms of consumer behaviour. This means a complete transformation of the current linear economic system, as well as innovation not only in technology but also in organisation, society, financing methods, and regulation.

The transition toward a circular economy can create new economic and employment opportunities and brings significant environmental and social benefits through a more efficient use of resources. A group of developed countries, including the European Union (EU), play an important role in the development and implementation of the CE model. In the EU circular economy action plan, a circular economy is explained as an economy "where the value of products, materials and resources is maintained in the economy for as long as possible, and the generation of waste minimised" (European Commission, 2015, p. 1).

The concept of circular economy has gained in appeal in the last decade among both academics and practitioners. It is much more tangible and manageable for businesses than sustainable development that is now more than thirty years old (United Nations, 1987) but it is still a widely disputed concept (Ghisellini et al., 2016; Murray et al., 2017). The latter is too 'fuzzy' to be operationally feasible, and thus, while widely used in both academia and policy discourse, it is considered by many to be increasingly losing its appeal and momentum. Moreover, Naudé (Naudé, 2011) called it a 'theoretical dream' rather than an 'implementable reality'. According to Engelman (Engelman, 2013), the spreading of the term 'sustainable development' ranges from 'environmentally better' to 'cool'. The concept of green economy (UNEP, 2011) and green growth (OECD, 2011) both aiming at sustainable development may also be conceptual frameworks that deserve attention for both enterprises and policy-makers but the concept of circular economy is the one that is the focus of attention today (Ellen MacArthur Foundation, 2014a, 2014b; Ernst \& Young Accountants LLP, 2014). According to Kirchherr et al. (2017), there are 114 different definitions of circular economy in scientific literature.

Many countries have already demonstrated their commitments to enhancing their transitions towards a circular economy, which is often expressed in a national CE policy statement or as part of a broader environmental strategy. For example, to refer to a circular economy, OECD countries use various terms such as resource productivity and sustainable materials management ${ }^{1}$ (OECD, 2019).

\footnotetext{
${ }^{1}$ Sustainable materials management (SMM) is a systemic approach to using and reusing materials more productively over their entire life cycles.
} 
Resource productivity (RP) measures the direct use of the total amount of materials in an economy (counted as GDP over DMC). It shows how efficiently an economy uses material resources to create human well-being that is to create more (value) from less (material input). DMC derived from economy-wide material flow accounts provides an assessment of the absolute level of resource utilisation and refers to apparent consumption.

According to current experiences of OECD countries, "a key barrier to the implementation of a comprehensive and coherent circular economy policy mix can be the absence of an effective institutional framework. In order to develop and implement policies that support the move to a circular economy, countries should seek to build broad government support and inter-ministerial co-ordination for effective policies that address all stages of the materials life-cycle," (OECD, 2019, p. 27). CE strategies and/or policies require wide-range institutional co-operation involving all relevant players, including ministries for economic development, and ensuring that circular economy objectives are integrated across all environment-related policy areas (Flynn et al., 2019; Sassanelli et al., 2019; Grdić et al., 2020; Momete, 2020).

In 2004, Visegrad countries (V4) consisting of the Czech Republic, Hungary, Poland, and Slovakia joined the EU and inherited the energy and material intensive economy from the former socialist regime. Since the early 1990s, these post-socialist countries have been striving to catch up with the development level of the European Union and boost competitiveness, which requires much more efficient use of natural resources.

The Visegrad Group is a regional configuration within the EU, where there are regular consultations at the top state and government level, ministerial level, and expert level. V4 countries mainly coordinate their positions on relevant EU regulations and policies. The main task of the annually rotating presidency is to manage intensive intergovernmental co-operation, develop common positions, organise political and expert meetings, and launch common projects. According to 2019 data, the countries of the Visegrad Group have a population of 63.8 million, which accounts for 12.4 per cent of the total population of the EU and they together generate 6 per cent of the GDP of the European Union.

The primary purpose of this article is to provide a comparative presentation of the main policy measures adopted individually by the four Central European countries participating in the Visegrad co-operation to move their current national "mainstream" (linear) economies towards circular economies.

The secondary goal is to compare the effectiveness of the state policy performances of V4 countries to each other and to other groups of EU Member States at the macro level using certain elements of the EU's set of key indicators for monitoring circular economy (European Commission, 2018c). The notion of CE involves not only the recycling of materials coming from nature to the socio-economic system but also the reduction of consumption itself; the indicators selected 
for this analysis cover not only municipal waste generation and management but also resource productivity in Visegrad countries.

In Section 2 methodological issues and data sources used for comparison are described. Section 3 provides a brief overview of circular economy-related policies of the European Union, while Section 4 presents CE-related policy initiatives and relevant progress in Visegrad countries. In Section 5 some important results are presented and discussed together with brief conclusions.

\section{METHODOLOGICAL ISSUES AND DATA SOURCES}

To achieve the main objective of comparing V4 initiatives, we have carefully selected the relevant official documents dealing with CE-related issues elaborated and presented by V4 governments or their affiliated bodies. We studied only those policy documents which had been adopted (or waiting for final approval) by the Parliament or the government, and they could have been downloaded from any of the official websites or were available in hard copies. We excluded from our research plans not yet adopted and documents under discussion.

In general, the role of using indicators is very important in evaluating, monitoring, and developing the various policies and programmes aimed at the implementation of the circular economy concept. In the transition to a more circular economy, monitoring the key trends and patterns is a prerequisite to understanding how the different driving forces of a circular economy are evolving (European Commission, 2018c). In close cooperation with the European Environment Agency and consultations with Member States, the Commission has developed a monitoring framework for circular economy, designed to measure progress effectively based on reliable existing data (European Commission, 2018c). This monitoring framework consists of four broader themes (production and consumption, waste management, secondary raw materials, competitiveness, and innovation) and includes 10 key indicators and together with sub-indicators totals 21 indicators (Table 1). We have chosen one indicator as a sample from each group for further examination. The selection criteria were: (1) offer time series, and (2) be representative for a wider topic rather than focus on specific sub-issues. All the data used for country comparisons was taken from the Eurostat database $^{2}$ including CE-related tables ${ }^{3}$. All the data applies to the most recent year available.

\footnotetext{
${ }^{2}$ https://ec.europa.eu/eurostat/data/database [accessed on: 04.04.2020]

${ }^{3}$ https://ec.europa.eu/eurostat/web/circular-economy/indicators/main-tables [accessed on: 04.04.2020]
} 
Table 1. Indicators for monitoring the EU's progress towards the circular economy (CEI)

\begin{tabular}{|c|c|c|}
\hline & CE Indicator (CEI) & Coverage-Time \\
\hline & \multicolumn{2}{|l|}{ Production and Consumption } \\
\hline 1 & EU self-sufficient for raw material & \\
\hline 2 & Green Public Procurement & \\
\hline 3 & Waste generation & \\
\hline $3 a$ & Generation of municipal waste per capita ( $\mathrm{kg}$ per capita) & $>10$ years $(2000)$ \\
\hline $3 b$ & $\begin{array}{l}\text { Generation of waste excluding major mineral waste per GDP unit } \\
\text { (kg per thousand euro, chain-linked volumes (2010) }\end{array}$ & $>10$ years $(2004)$ \\
\hline $3 \mathrm{c}$ & $\begin{array}{l}\text { Generation of waste excluding major mineral waste per domestic } \\
\text { material consumption (percentage) }\end{array}$ & $>10$ years $(2004)$ \\
\hline \multirow[t]{2}{*}{4} & Food waste (million tons) & \\
\hline & Waste Management & \\
\hline 5 & Recycling rates & \\
\hline $5 a$ & Recycling rate of municipal waste (percentage) & $>10$ years $(2000)$ \\
\hline $5 b$ & $\begin{array}{l}\text { Recycling rate of all waste excluding major mineral waste } \\
\text { (percentage) }\end{array}$ & 5 to $10(2010)$ \\
\hline 6 & Recycling/recovery for specific waste streams & \\
\hline $6 a$ & Recycling rate of overall packaging (percentage) & $>10$ years $(2000)$ \\
\hline $6 b$ & Recycling rate of plastic packaging (percentage) & $>10$ years $(2000)$ \\
\hline $6 c$ & Recycling rate of wooden packaging (percentage) & $>10$ years $(2000)$ \\
\hline $6 \mathrm{~d}$ & Recycling rate of e-waste (percentage) & 5 to $10(2010)$ \\
\hline $6 e$ & Recycling of biowaste (kg per capita) & $>10$ years $(2000)$ \\
\hline \multirow[t]{2}{*}{$6 f$} & Recovery rate of construction and demolition waste (percentage) & 5 to $10(2010)$ \\
\hline & Secondary Raw Materials & \\
\hline 7 & Contribution of recycled material to raw materials demand & \\
\hline $7 \mathrm{a}$ & End-of-life recycling input rates (EOL-RIR) (percentage) & 2016 \\
\hline $7 b$ & Circular material use rate (percentage) & $>10$ years $(2010)$ \\
\hline \multirow[t]{2}{*}{8} & Trade in recyclable raw materials (tonnes) & $>10$ years $(2004)$ \\
\hline & Competitiveness and Innovation & \\
\hline 9 & Private investments, jobs and gross value added related to $\mathrm{CE}$ sectors & \\
\hline $9 \mathrm{a}$ & $\begin{array}{l}\text { Gross investments in tangible goods (percentage of GDP at current } \\
\text { prices) }\end{array}$ & $>10$ years $(2012)$ \\
\hline $9 b$ & Persons employed (percentage of total employment) & $>10$ years $(2012)$ \\
\hline $9 \mathrm{c}$ & Value added at factor cost (percentage of GDP at current prices) & $>10$ years $(2012)$ \\
\hline 10 & Number of patents related to recycling and secondary raw materials & $>10$ years $(2000)$ \\
\hline
\end{tabular}

Note: indicators in italic are discussed in the article

Source: European Commission (2018c). 


\section{CIRCULAR ECONOMY-RELATED POLICIES OF THE EUROPEAN UNION}

The implementation of a circular economy requires long-term commitment at all levels, from Member States, regions and cities to businesses and citizens, as well as not only at the EU level but also at the global level. The main ideas of the Roadmap to a Resource Efficient Europe (European Commission, 2011) were set out in more detail in the Seventh Environment Action Programme (2014-2020) (European Commission, 2014). (Fig. 1 and Fig. 2).

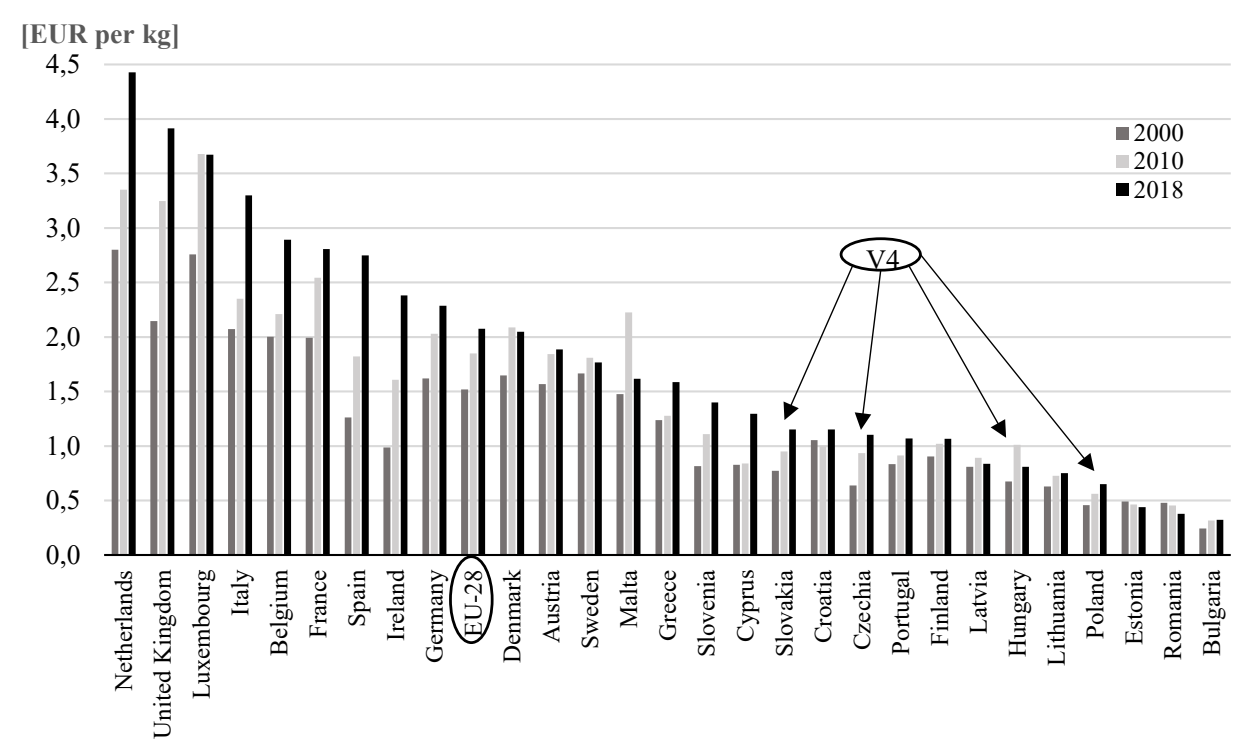

Fig. 1. Resource productivity in EU Member States, 2000-2018

Source: own work based on Eurostat data.

In 2015, the European Commission adopted the ambitious Closing the Loop - an EU Action Plan for Circular Economy (European Commission, 2015), which includes measures that will help push Europe's transition towards a circular economy, boost global competitiveness, foster sustainable economic growth, and create new jobs. The Action Plan incorporates a series of aspiring and focused measures covering the entire cycle from production and consumption to waste management including the market for secondary raw materials and a revised EU-level legislative proposal on waste (European Commission, 2015). The proposed actions expectedly promote the 'closing of the loop' of product lifecycles via recycling and re-use at a higher rate, while bringing benefits for both the environment and the economy (European Commission, 2015). 


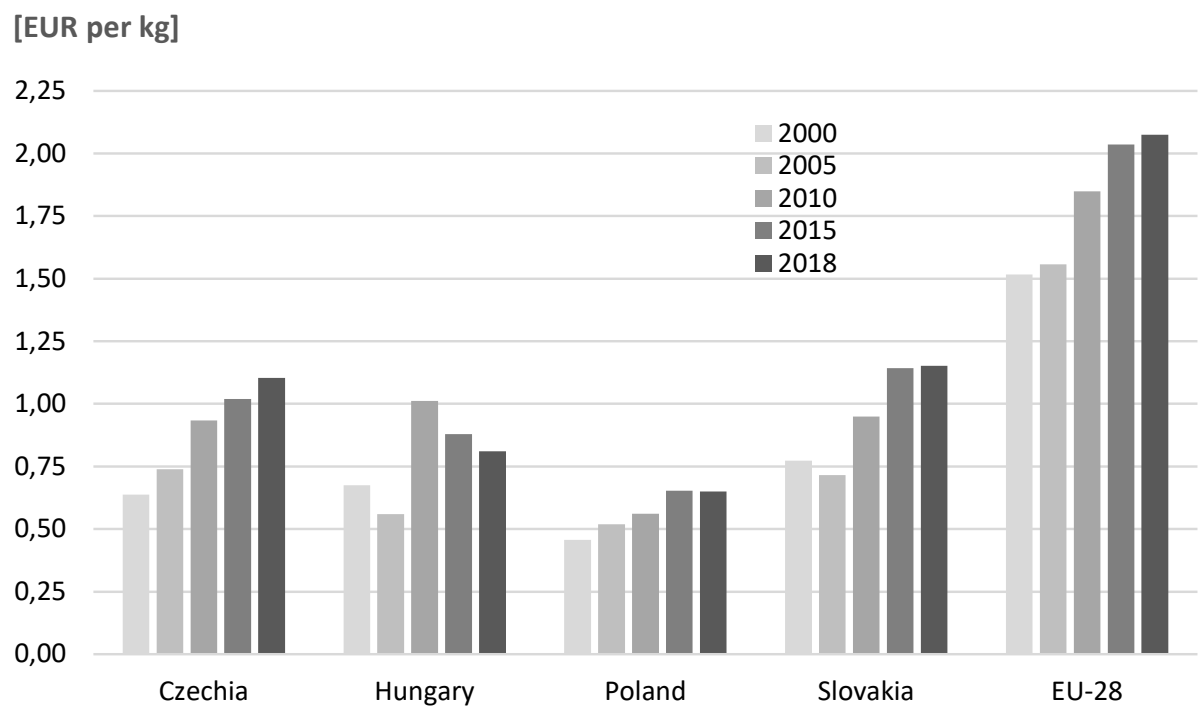

Fig. 2. Resource productivity in V4 countries

Source: own work based on Eurostat data.

The revised legislative framework directive on waste (European Commission, 2018b) entered into force in 2018. It defined clear targets for the reduction of waste and established an ambitious and credible long-term path for waste management and recycling (Table 2). Further key elements of the revised waste proposal include a binding landfill target to reduce landfill use to a maximum of 10 per cent of municipal waste by 2035; and separate collection obligations are strengthened and extended to hazardous household waste (by the end of 2022), bio-waste (by the end of 2023), and textiles (by the end of 2025) (European Commission, 2015).

Table 2. Targets of waste recycling rate for 2025 and 2030 at EU level

\begin{tabular}{|l|c|c|}
\hline Type of waste & By 2025 & By 2030 \\
\hline All packaging & 65 & 70 \\
\hline Paper and cardboard & 75 & 85 \\
\hline Ferrous metals & 70 & 80 \\
\hline Glass & 70 & 75 \\
\hline Aluminium & 50 & 60 \\
\hline Plastic & 50 & 55 \\
\hline Wood & 25 & 30 \\
\hline
\end{tabular}

Source: European Commission (2015). 
A European Strategy for Plastics in a Circular Economy (European Commission, 2018a) adopted in 2018, the first-ever strategy on plastics, is a decisive part of the transition towards a more circular economy. The strategy aims at reducing the pressure on the environment coming from plastic pollution whilst fostering growth and innovation. Under the new plan, all plastic packaging waste on the EU market will be recyclable by 2030 , the consumption of single-use plastics will be reduced, and the intentional use of microplastics will be restricted.

The European Green Deal published in late 2019 represents a new growth strategy aiming at transforming the EU into a fair and prosperous society, with a modern, resource-efficient and competitive economy where in 2050 there are no net emissions of greenhouse gases and where economic growth is decoupled ${ }^{4}$ from resource use (European Commission, 2019d).

In 2020, the European Commission adopted a new Circular Economy Action Plan (European Commission, 2020b) - one of the main building blocks of the European Green Deal. The new Action Plan covers initiatives regarding the whole product life cycle, such as targeted product design, fostering CE processes, promoting sustainable consumption, and keeping the circulation of materials inside the economy for as long as possible. A New Industrial Strategy for Europe emphasises that industry must play a leading role in the ecological transition by reducing its carbon and material footprint and embedding circularity across the economy (European Commission, 2020a).

Appropriate objectives and indicators have played a key role in the overall process of developing and implementing the abovementioned policies. In 2011 Eurostat compiled a milestone methodological guide (Eurostat, 2001) for measuring economy-wide material flow and resource productivity (Fig. 2), followed by additions and improvements in 2009 and 2018 (Eurostat, 2009; Eurostat, 2018).

Since 2013, the European Commission has been publishing the Resource Efficiency Scoreboard as part of the Europe 2020 indicators. The aim is to monitor the implementation of the Roadmap to a Resource Efficient Europe, to demonstrate the link between resources, and to involve stakeholders even more in the process of measuring social development beyond GDP.

\section{CIRCULAR ECONOMY-RELATED POLICIES AND PROGRESS IN VISEGRAD COUNTRIES}

In the last five years, V4 presidencies several times discussed the EU proposals on circular economy and waste management (Visegrad Group Presidency Programmes, 2018). The transition toward resource-efficient, low carbon and

\footnotetext{
${ }^{4}$ Decoupling occurs when the growth rate of environmental pressure is less than that of its economic driving force (e.g. GDP) over a given period.
} 
circular economy represents a common challenge for all these countries. The Czech Presidency programme for 2019-2020 identified broad priority areas for enhanced co-operation. Concerning circular economy, the Czech Presidency programme focused on boosting the market for recyclables and secondary raw materials; promoting the efficient use of resources (Fig. 3) to prevent waste generation at all levels; increasing waste recycling rates and reuse (Fig. 4); radically reducing landfilling (Fig. 5); increasing the substitution of secondary for primary materials (Fig. 6); promoting eco-design of products; promoting technologies for effective use of primary raw materials and extraction, processing and use of secondary raw materials following the EU Action Plan for the Circular Economy (and related national strategies, policy concepts and policies) (Czech Presidency, 2019).

The present Polish presidency programme (2020/2021) highlights the importance of a common approach in CE initiatives; the exchange of experiences between central and local government officials, scientific units and research institutes on the one hand, and members of industry, in particular bioindustry of V4 countries responsible for planning, implementing and financing bioeconomy (an approach akin to the circular economy) activities, on the other (Polish Presidency, 2020).

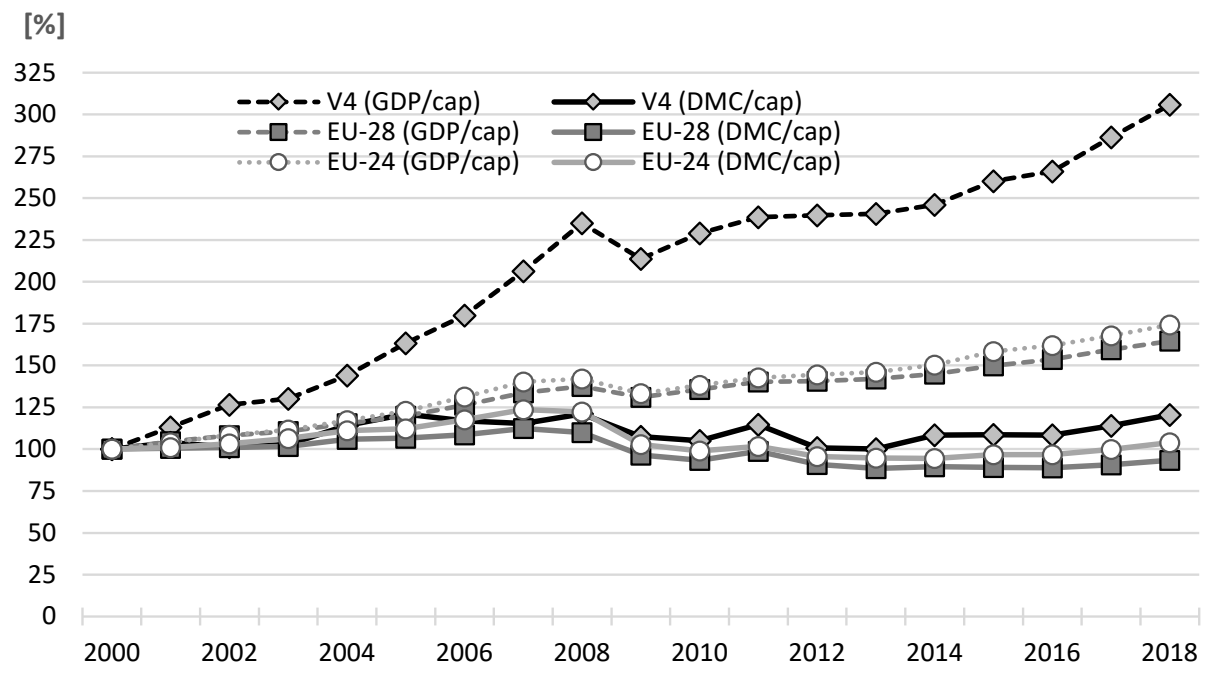

Fig. 3. Decoupling of GDP from domestic material consumption (DMC) by EU countries' groups, 2000-2018

Note: EU-24: excludes V4 from EU-28

Source: own work based on Eurostat data. 
[\%]

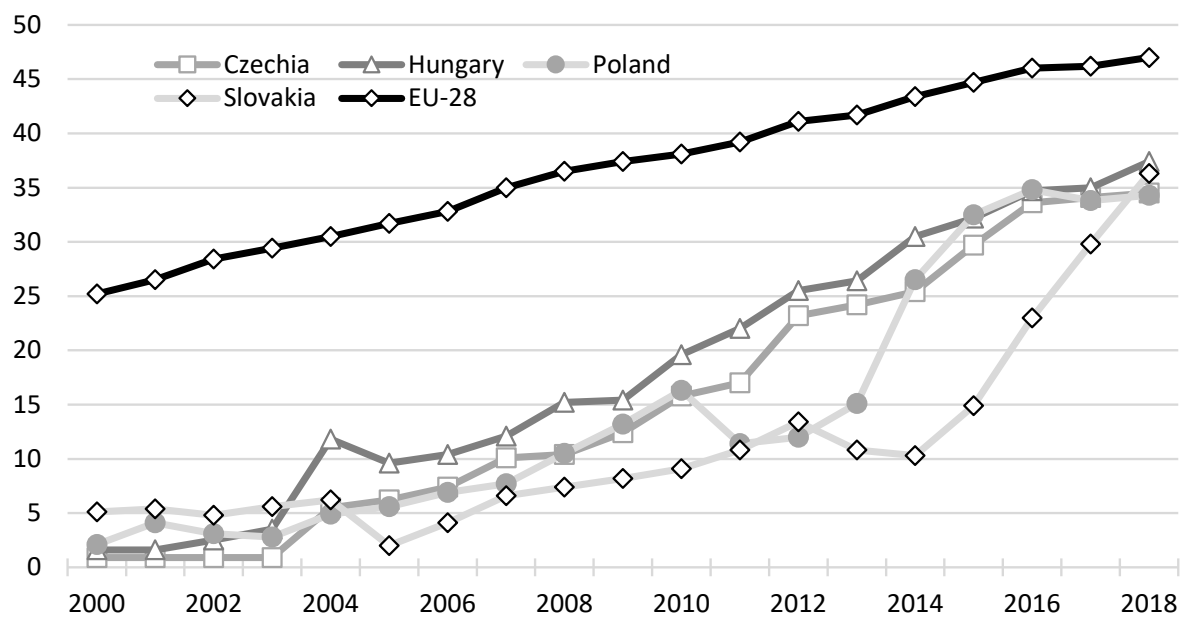

Fig. 4. Recycling rate of municipal waste in V4 countries, 2000-2018

Source: own work based on Eurostat data.

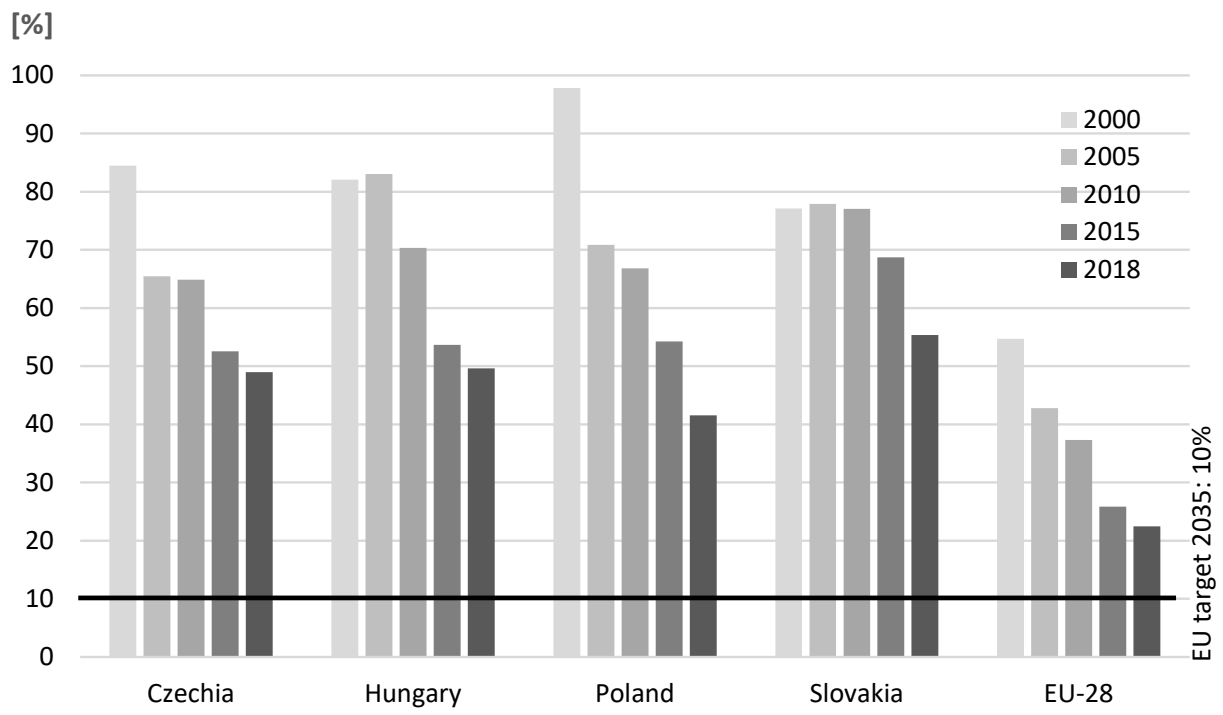

Fig. 5. Landfill rate of municipal waste in V4 countries, 2010-2018

Source: own work based on Eurostat data. 


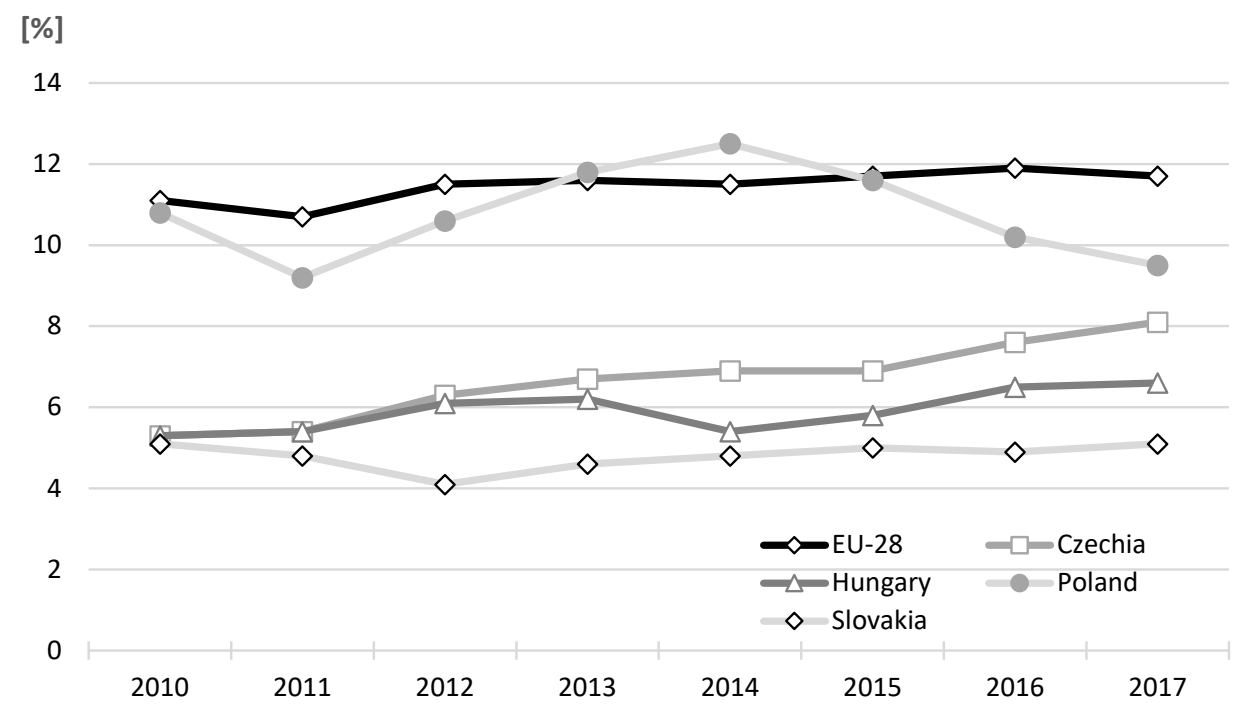

Fig. 6. Circular material use rate in V4 countries, 2010-2017

Source: own work based on Eurostat data.

A synoptic view of the annual change rates of DMC and GDP provides insights into the degree of decoupling 5 . Fig. 7 illustrates how far decoupling has been achieved in V4 and EU economies. The diagonal line denotes identical annual change rates of both GDP and DMC. Countries placed above this line have higher DMC growths than GDP growths and do not manage to decouple the two parameters simultaneously. Countries with faster growth of GDP than of DMC (relative decoupling) can be found below the diagonal line. Absolute decoupling occurs when DMC decreases while GDP increases. In the last two decades, the latter situation could not be observed in either Visegrad country. Fig. 7 highlights the years when individual V4 countries achieved their best and worst performances since 2000. One can see that V4 countries' worst performances occurred around the world economic crisis in 2008/2009 showing a strong relative decoupling. All the countries, after successful economic crisis management, achieved record growths both in GDP and material input propelling them towards the diagonal, i.e. to the border of no decoupling territory or beyond it. The process culminated between 2011 and 2014. Hungary looks like an extremist: on the one hand it spent 7 years in the no decoupling area, while in two years it was twice the best performer in the relative decoupling field. This high fluctuation shows, to a certain degree, the vulnerability of the Hungarian

\footnotetext{
${ }^{5}$ Recently, Antczak (2019) investigated the decoupling issue regarding municipal waste generation in Poland.
} 
economy. The remaining three countries present more even trends with lower fluctuations, only Poland's economy indicates a somewhat similar economic and material use trajectory. V4 countries' mean performance slightly moved to the border of no decoupling but most of the time it remained in the relative decoupling territory. In the meanwhile, the EU-28 average also moved to this border, however, with a considerably narrower fluctuation.

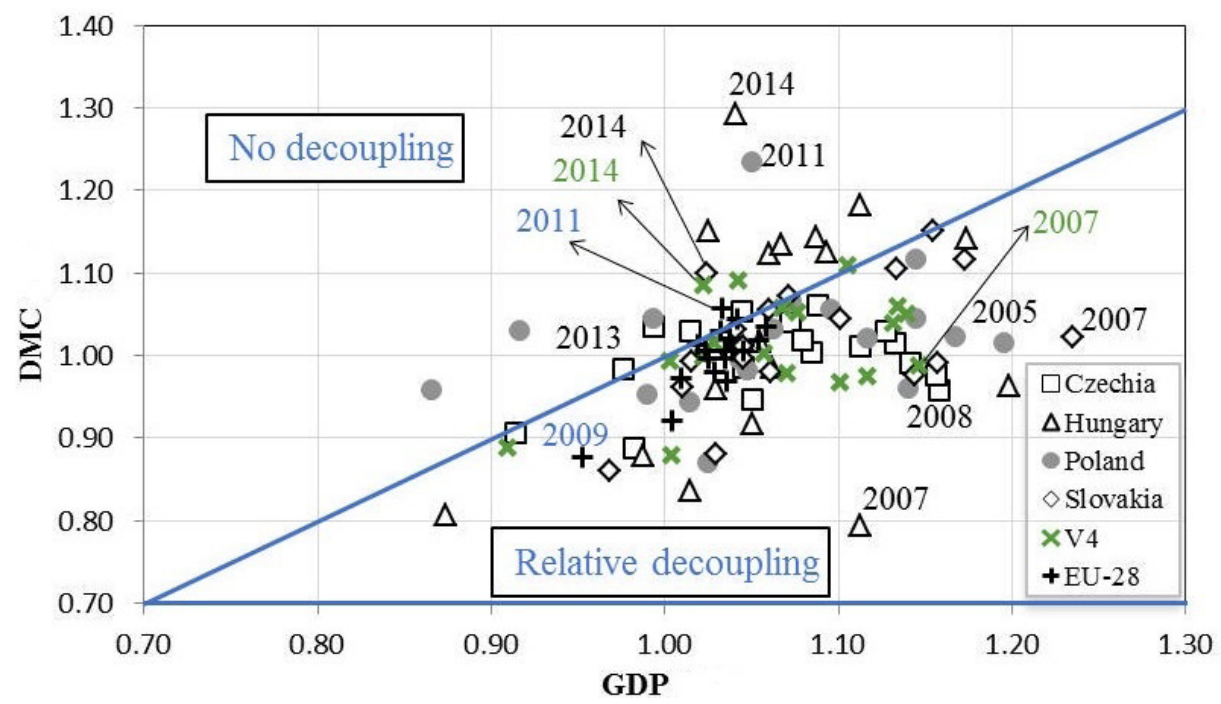

Fig. 7. Annual change rate of DMC and GDP in V4 countries, 2000-2018

Source: own work based on Eurostat data.

\subsection{The Czech Republic}

The 2012-2020 State Environmental Policy of the Czech Republic (SEP, updated in 2016) established a strategic framework for effective protection of the environment in the Czech Republic until 2020. The main objective of the Policy has been to ensure a healthy and high-quality environment for citizens, to significantly contribute to a more effective use of resources, and to minimise the negative impacts of human activities on the environment, including cross-border impacts, and thus contribute to the improvement of quality of life in Europe and worldwide. The SEP focuses on the following areas: the protection and sustainable use of resources; climate protection and improvement of ambient air quality; the protection of nature and landscape (Ministry of the Environment of the Czech Republic, 2012). According to the SEP, energy and 
material intensity of the Czech economy is expected to decrease, and the environmental pressures (emissions into the air and water, impacts on landscape, waste generation, etc.) per unit of economic output will decrease. In general, the country supports CE principles and strategic direction, which enhances the management of waste as a resource.

In 2014, the Czech Government adopted the National Waste Management Plan for 2015-2024, which contains national waste prevention measures as well (Ministry of the Environment of the Czech Republic, 2014). It aims at enhancing the transition to a circular economy in the long term. Despite this political goal, there are only limited CE initiatives, as well as eco-innovative companies introducing the creative environmental, and ecological and socially responsible solutions (Švecová et al., 2019). At the same time, regional waste management plans were also approved. All these efforts are expected to contribute to achieving long term recycling targets and promoting transition towards a circular economy.

In 2017, the 2030 Strategic Framework was adopted by the Government, describes such a development model in which the energy and material intensity of the economy will be reduced. The main strategic goal of this document is the most efficient and economical use of natural resources to minimise the external costs of their consumption. There is a need to reduce the intensity of greenhouse gas emissions connected with the production of gross domestic product (GDP) and increase energy and material efficiency (Office of the Government of the Czech Republic, 2019). The basis for the long-term economic growth is ensured by entrepreneurship, innovation, human creativity and skills, high value-added industries, circular economy, low carbon technologies, robotics, and digitalisation. This model is based on the principles of a social market economy, and in its centre there lies co-operation and co-ordination between public administration, business and civil society (Ministerstvo životniho prostŕedi, 2020).

The country has no specifically defined national CE strategy or a roadmap yet. Preparations for establishing a national strategy called Circular Czech Republic 2040 are still at an early stage, adoption is expected in 2020 (European Commission, 2019a). The CE concept and eco-innovation are still emerging fields in comparison with western and northern EU Member States, and there are many barriers related to human resources (e.g. a lack of knowledge) and targeted financing, particularly in the business sphere (Švecová et al., 2019).

According to an OECD evaluation, the country performance in waste management is modest (Table 3). The country will have to take significant steps before moving towards a circular economy. The country emphasises the value of waste as a resource promoting reuse, recycling, and waste prevention. The implementation of these should be continued in parallel with the modernisation of the Czech economy, aligning different policies and efficient co-operation between relevant ministries (OECD, 2018a). 
Table 3. Comparison of Visegrad countries by selected indicators, 2000-2018

\begin{tabular}{|c|c|c|c|c|c|c|}
\hline & Year & $\mathbf{C Z}$ & HU & PL & SK & EU-28 \\
\hline \multirow{5}{*}{$\begin{array}{l}\text { Municipal waste generation, } \mathrm{kg} / \mathrm{cap} \\
\text { [CEI } 3 a]\end{array}$} & 2000 & 335 & 446 & 320 & 254 & 521 \\
\hline & 2005 & 289 & 461 & 319 & 273 & 515 \\
\hline & 2010 & 318 & 403 & 316 & 319 & 504 \\
\hline & 2015 & 316 & 377 & 286 & 329 & 481 \\
\hline & 2018 & 351 & 381 & 329 & 414 & 489 \\
\hline \multirow[t]{5}{*}{ Municipal waste treatment, $\mathrm{kg} / \mathrm{cap}$} & 2000 & 317 & 407 & 320 & 249 & 497 \\
\hline & 2005 & 244 & 457 & 245 & 257 & 483 \\
\hline & 2010 & 304 & 403 & 264 & 309 & 492 \\
\hline & 2015 & 316 & 377 & 286 & 310 & 470 \\
\hline & 2018 & 351 & 383 & 329 & 414 & 481 \\
\hline \multirow{5}{*}{$\begin{array}{l}\text { Municipal waste recycling rate, } \% \\
{[C E I 5 a]} \\
\text { EU target: } 50 \%(2020), 60 \%(2030)\end{array}$} & 2000 & 0.9 & 1.6 & 2.1 & 5.1 & 25.2 \\
\hline & 2005 & 6.2 & 9.6 & 5.6 & 2 & 31.7 \\
\hline & 2010 & 15.8 & 19.6 & 16.3 & 9.1 & 38.3 \\
\hline & 2015 & 29.7 & 32.2 & 32.5 & 14.9 & 44.7 \\
\hline & 2018 & 34.5 & 37.4 & 34 & 36 & 47 \\
\hline \multirow{5}{*}{$\begin{array}{l}\text { Municipal waste landfilling rate, } \% \\
\text { EU target: } 10 \%(2035)\end{array}$} & 2000 & 84.4 & 82.1 & 97.9 & 77.1 & 54.7 \\
\hline & 2005 & 65.5 & 83.1 & 70.9 & 77.9 & 42.8 \\
\hline & 2010 & 64.8 & 70.4 & 66.8 & 77.1 & 37.3 \\
\hline & 2015 & 52.6 & 53.6 & 54.3 & 68.7 & 25.8 \\
\hline & 2018 & 49 & 49.6 & 41.6 & 55.4 & 22.5 \\
\hline \multirow[t]{4}{*}{ Circular material use, $\%$ [CEI $7 b]$} & 2005 & . & . & . & . & 8.9 \\
\hline & 2010 & 5.3 & 5.3 & 10.8 & 5.1 & 11.1 \\
\hline & 2015 & 6.9 & 5.8 & 11.6 & 5 & 11.7 \\
\hline & 2018 & 8.1 & 6.6 & 9.5 & 5.1 & 11.7 \\
\hline \multirow{4}{*}{$\begin{array}{l}\text { Patents related to recycling and } \\
\text { secondary raw materials, per million } \\
\text { cap. [CEI 10] }\end{array}$} & 2000 & 1.07 & 0.08 & 0.33 & 0.39 & 0.64 \\
\hline & 2005 & 0.73 & 0.1 & 0.33 & 0 & 0.61 \\
\hline & 2010 & 1.84 & 0.61 & 0.09 & 0.09 & 0.67 \\
\hline & 2015 & 0.91 & 0.14 & 0.77 & 1.14 & 0.7 \\
\hline \multirow{5}{*}{$\begin{array}{l}\text { Domestic Material Consumption } \\
(\mathrm{DMC}), \mathrm{t} / \mathrm{cap}\end{array}$} & 2000 & 17.5 & 11.7 & 14.1 & 10.1 & 15.1 \\
\hline & 2005 & 18.4 & 17.7 & 14.5 & 14 & 15.9 \\
\hline & 2010 & 16 & 9.8 & 17 & 13.3 & 13.8 \\
\hline & 2015 & 15.9 & 12.7 & 16.9 & 12.5 & 13.1 \\
\hline & 2019 & 16.1 & 17.6 & 18.5 & 13 & 13.4 \\
\hline
\end{tabular}




\begin{tabular}{|l|c|c|c|c|c|c|}
\cline { 2 - 7 } \multicolumn{1}{c|}{} & Year & CZ & HU & PL & SK & EU-28 \\
\hline Gross Domestic Product (GDP), & 2000 & 11170 & 7900 & 6440 & 7780 & 22968 \\
\cline { 2 - 7 } EUR/cap. & 2005 & 13570 & 9910 & 7510 & 9960 & 24820 \\
\cline { 2 - 7 } & 2010 & 14900 & 9900 & 9390 & 12540 & 25500 \\
\cline { 2 - 7 } & 2015 & 16160 & 11130 & 10920 & 14270 & 26680 \\
\cline { 2 - 7 } & 2018 & 18000 & 13180 & 12980 & 15890 & 28650 \\
\hline Resource productivity (RP=GDP/ & 2000 & 0.64 & 0.67 & 0.46 & 0.77 & 1.52 \\
\cline { 2 - 7 } DMC), EUR/kg & 2005 & 0.74 & 0.56 & 0.52 & 0.72 & 1.56 \\
\cline { 2 - 7 } & 2010 & 0.93 & 1.01 & 0.56 & 0.95 & 1.85 \\
\cline { 2 - 7 } & 2015 & 1.02 & 0.88 & 0.65 & 1.14 & 2.05 \\
\cline { 2 - 7 } & 2018 & 1.12 & 0.75 & 0.71 & 1.22 & 2.14 \\
\hline \multirow{4}{*}{$\begin{array}{l}\text { Decoupling DMC from GDP, \% } \\
\text { (base year: 2000) }\end{array}$} & 2000 & 0 & 0 & 0 & 0 & 0 \\
\cline { 2 - 7 } & 2005 & 60 & 29 & 30 & 38 & 13 \\
\cline { 2 - 7 } & 2010 & 139 & 114 & 75 & 172 & 42 \\
\cline { 2 - 7 } & 2015 & 155 & 119 & 112 & 231 & 61 \\
\cline { 2 - 7 } & 2018 & 210 & 141 & 131 & 263 & 71 \\
\hline
\end{tabular}

Note: Shaded rows refer to the elements of the European Commissions' set of indicators for monitoring CE

Source: own work based on Eurostat data.

\subsection{Hungary}

The development of a circular economy action plan is still in its infancy. Although there is no separate policy framework for the development of a circular economy, several national strategic planning documents also address material and resource management issues to some extent, either directly or indirectly. The 2011-2020 National Environmental Technology Innovation Strategy (NETIS), the 20122024 National Sustainable Development Framework Strategy (NSDFS), and the 4th National Environmental Protection Programme (NEPP) for the period 20152020 have all identified material and resource efficiency as one of the policy goals.

The 2011-2020 NETIS (Government of Hungary, 2011) adopted in 2011 includes 17 targets for sustainable resource management by 2020, shows how efforts are being made to include resource efficiency, and CE considerations into some sectoral policies. The strategy includes a measurable target to reduce the material intensity of the economy by 20 per cent by 2020 in comparison with the base year of 2007, and the country is on a good track to achieving the target. 
The 2012-2024 NSDFS (National Sustainable Development Council of Hungary, 2013) adopted in 2013 includes a regular monitoring of the state (both the quality and quantity) of natural resources and unsustainable trends and defines the desirable development directions. The 4th NEPP 2015-2020 (Hungarian Parliament, 2015) represents a strategic six-year plan for environmental and nature protection. It encompasses several different strategies and could, therefore, be an adequate starting point for planning the transition towards a circular economy. This programme also identifies resource efficiency as a policy priority.

The 2014-2020 National Waste Management Plan adopted in 2013 has been under revision since 2017 (Government of Hungary, 2013). One reason was so that it could consider the requirements of the EU circular economy package (2015), which was adopted in the meantime. The national waste management plan is complemented by its annual waste collection and utilisation service plans. The prevention and reduction of waste generation and increasing reuse and recycling rates (Fig. 4, Table 3) could make the country more resource-efficient while creating new business opportunities. It could also contribute to a more real transition to a circular economy by providing jobs in the recycling industry (European Commission, 2019b).

In the early 2020, The Hungarian Business Council for Sustainable Development published the findings of a survey on circular economy. According to the respondents, there was a clear need for a better understanding of CE solutions, sharing good practices, applying state incentives, and developing a national $\mathrm{CE}$ strategy (BCSDH, 2019).

The EU's 2017 Environmental Implementation Review included a suggested action for Hungary to develop an overarching CE policy framework. However, there are some challenges in this process, in particular, a lack of institutional coordination and a lack of dedicated funding. Initial expert dialogues and consultations mainly involved the waste management sector (European Commission, 2019b). Since the reshuffling of the Government in the mid-2018, the CE-related questions no longer belong to the Ministry of Agriculture, but to the Ministry for Innovation and Technology, which is also responsible for waste management issues.

The Hungarian Performance Review of the OECD published in the mid-2018 stated that the Government was looking at a transition towards circular economy as a pure waste management question. Other aspects of circular economy like sustainable material management were considered to a limited extent. The OECD has formulated an essential policy recommendation: "Introduce a whole-of-government approach through collaboration between relevant ministries to steer the transition to a circular economy; develop a national circular economy action plan with measurable targets and timelines" (OECD, 2018b, p. 39). 


\subsection{Poland}

In July 2019, the Council of Ministers adopted the 2030 National Environmental Policy (Polityka Ekologiczna Państwa, PEP2030). PEP2030 has become the most important strategic document in the area of the environment and water management (Council of Ministers of Poland, 2019a). The role of PEP2030 is to ensure Poland's ecological safety and high quality of life for all residents. PEP2030 will be the basis for investing European funds from the financial perspective 2021-2027. PEP2030 also supports the implementation of Poland's objectives and commitments at the international level, including those of the EU and the UN, especially in the context of the EU's climate and energy policy objectives by 2030 and the sustainable development goals (SDGs) included in the Agenda 2030 (Council of Ministers of Poland, 2019a). The effectiveness of the implementation of PEP2030 will be monitored using a set of indicators (over 20, for example, municipal waste recycling rate) based on data from reliable sources, in particular, the State Environmental Monitoring System, Statistics Poland and the General Inspectorate for Environmental Protection.

One of the specific objectives of the PEP2030 is to ensure a sustainable management of environmental resources. There are two directions of implementation closely related to a circular economy: waste management towards a circular economy and managing geological resources by developing and implementing a State Raw Materials Policy (by 2050) (Ministry of Environment, 2019). The actions aim to fully implement a waste hierarchy in Poland in line with the concept of circular economy. First of all, it is necessary to ensure the implementation of actions which are at the highest levels of the waste hierarchy, i.e. prevent waste generation and create an indispensable infrastructure for separate waste collection at the source to ensure its preparation for reuse or effective recycling. These actions will also support climate protection by reducing greenhouse gas emissions from the waste management sector, mainly from landfills (Fig. 5).

The fundamental instrument for implementing PEP2030 in this area is the National Waste Management Plan 2022 (Krajowy plan gospodarki odpadami 2022, KPGO 2022). It was prepared to achieve waste management targets, implement the waste hierarchy and the principles of self-sufficiency and proximity, and to create and maintain an integrated and adequate network of waste management installations.

In September 2019, following a wide range of public consultations, the Council of Ministers approved the Roadmap towards a Transition to Circular Economy in Poland. The Roadmap prepared by the Interdepartmental Circular Economy Group under the umbrella of the Polish Ministry of Development indicates activities that primarily contribute to reducing waste and to the introduction of the CE model in Poland (Council of Ministers of Poland, 2019b). The Roadmap identifies actions to maximise the added value of raw materials/resources, materials and 
products, and reduce waste generation while maintaining the condition of production efficiency and consumption processes. The document also comprises a set of legislative and non-legislative tools to foster the development of CE in Poland in the areas of sustainable industrial production, consumption, bioeconomy, and new business models. There are 41 measures proposed in these areas, assigned to relevant ministries. It also includes a separate action to develop a conceptual framework for monitoring the circular economy in Poland.

The Commission's "early warning report" named Poland among the countries unlikely to achieve the municipal waste recycling target by 2020 (Fig. 4, Table 3). More efforts will be necessary to meet the recycling targets set for the period after 2020 (European Commission, 2019c).

A research study identified transition barriers to a circular economy in Poland: a lack of funding, social barriers (a low level of public awareness, e.g. concerning proper selective waste collection), and technological barriers (a low level of eco-innovation) (Zielińska, 2019). Poland's embracing of the CE would be extremely beneficial from the macroeconomic point of view. The economy of closed loops could stimulate economic growth, and calculations show that even a minimal change in the Polish economy, i.e. a 1 per cent savings in the cost of materials and energy - could result in annual GDP growth of EUR 4.5 billion (Deloitte, 2018)

\subsection{Slovakia}

The Strategy of the Environmental Policy of the Slovak Republic by 2030 (Envirostrategy 2030) (Ministerstvo životného prostredia SR, 2019) adopted in 2017 has defined a vision until 2030, and identified the fundamental systemic problems, set the objectives by 2030, and proposed a framework for measures to improve the current situation. It also contains basic performance indicators (e.g. municipal waste recycling rate, per capita waste generation, and municipal waste landfilling rate) that will enable a verification of the results. The biggest environmental challenges in Slovakia, and hence areas that will be prioritised within the environmental policy by 2030, are issues such as waste management, air quality, and habitat and species conservation, especially in forest, meadow, and wetland ecosystems.

The basic vision of Envirostrategy 2030 is to achieve better environmental quality and $\mathrm{CE}$, which is based on a rigorous protection of environmental resources and using as little non-renewable natural resources and hazardous substances as possible, which will lead to an improvement in public health. Environmental protection and sustainable consumption will be part of the general awareness of citizens and policymakers.

By 2030 , the municipal waste recycling rate, including its preparation for reuse, will increase to 60 per cent and by 2035 the land-filling rate will be reduced to less than 25 per cent. Slovakia will use green public procurement procedures 
for at least 70 per cent of the total value of public procurement. It will increase support for green innovation, science, and research. The disposal of food waste for supermarkets will be prohibited (Ministerstvo životného prostredia SR, 2019).

According to the European Commission's "early warning report" (European Commission, 2018e), Slovakia may not meet its municipal waste recycling rate target (Fig. 4, Table 3). The report recommended several urgent priority actions to be taken by Slovakia to bridge the implementation gap. The country will need to make greater efforts to meet post-2020 recycling targets.

The analytical work of the OECD clearly shows that better resource efficiency results in lower production costs and in the long term it improves economic competitiveness (OECD, 2016). It is of vital importance for a country with limited natural resources to implement coherent policies aiming at increasing resource efficiency and supporting green growth. A more efficient use of materials enhances both the decrease of domestic material consumption (DMC) and import dependency, the sooner these policies are being implemented the greater the economic and environmental benefits will be (OECD, 2017).

\section{DISCUSSION AND CONCLUSIONS}

The current performances of V4 countries in implementing the circular economic model lag behind the EU average, but a dynamic improvement of the presented indicators (excluding domestic material consumption) can be observed (Table 3, Fig. 3-6).

Resource productivity has improved significantly in V4 countries since the turn of the millennium (Fig. 1). The rate of municipal waste recycling in Hungary has barely lagged behind the EU average in the last few years, while that of the other countries is in the catching-up phase (Table 3). The circular material use ratio in the case of Poland is around the EU average, while the other three countries perform similarly but below the EU average (Fig. 6). Domestic material consumption decreased in the Czech Republic and Hungary, while it increased in Poland and Slovakia. The landfill rate has started to decline slowly in all V4 countries in recent years but it is still well above the EU average (Fig. 5).

The improvement showed by the selected indicators is likely to indicate the effectiveness of the wide range of the policy measures taken by V4 countries to support the transition to a circular economy.

To date, there has been no coherent Czech national policy that would include the CE, which is still just an emerging area in the Czech Republic. There are still many obstacles at the political level in terms of human resources and targeted funding, especially in the business sector. 
In Hungary, both from an institutional and financial points of view, it is a challenge to develop the necessary framework to comply with the EU CE package adopted in 2015. Multi-stakeholder dialogues and consultations on circular economy have started, mainly in the waste management sector and the public sphere. Although the strategic thinking on the integration of the CE concept into the Hungarian economy is not yet broad enough, there is a political will for it.

One of the main challenges in Poland today is to link waste management projects to other elements of the loops to increase performance in waste management. Work on the CE, and, in particular, the roadmap toward the CE, should reflect not only the establishment of the framework but also the links and synergies with other policies.

In Slovakia, too, a more efficient use of materials helps reduce domestic material use (Table 3 ) and import dependency while reducing the burden on the environment and natural resources. The current strong economic growth offers an opportunity to stimulate such a transition through carefully selected policy reforms and the necessary investments.

The selected indicators show that V4 countries' performance is improving, however, they still lag behind the EU average by 15-20 years (Table 3). It remains a general feature, and the performance is incremental rather than leapfrogging, therefore, the catching up will be a very long process at the current pace of implementation. To sum up, in all Visegrad countries, more ambitious policies, workable institutional system, and enabling regulatory frameworks are needed to achieve relevant EU targets. Managing the transition from the current economic model to a circular economy in Visegrad countries requires new approaches, integrated and coordinated policies, in particular, economic, social, technological, institutional, and environmental innovations.

It would be promising to explore the structural driving forces behind circular economy, as well as national/regional institutional and/or governance issues. An analysis of the relationship between $\mathrm{CE}$ and other policies (such as economic policies, innovation policies including eco-innovation) could also be an interesting subject.

\section{REFERENCES}

ANTCZAK, E. (2019), 'Municipal waste in Poland: Analysis of the spatial dimensions of determinants using geographically weighted regression', European Spatial Research and Policy, 26 (2), pp. 177-197. http://dx.doi.org/10.18778/1231-1952.26.2.09 [accessed on: 20.06.2020]

BCSDH (2019), Körforgásban az üzlet. Jelentés a körforgásos gazdaság magyarországi helyzetéröl, https://bcsdh.hu/programok/korforgasos-gazdasag-platform/helyzetjelentes-a-korforgasos-gazdasag-magyarorszagi-helyzeterol [accessed on: 15.04.2020] 
CIRCLE ECONOMY (2020), The Circularity Gap Report 2020, Amsterdam: Ruparo. https://www. circularity-gap.world/2020\#interactive [accessed on: 22.04.2020]

COUNCIL OF MINISTERS OF POLAND (2019a), Polityka ekologiczna państwa 2030 - strategia rozwoju w obszarze środowiska i gospodarki wodnej, https://www.gov.pl/web/climate/ the-2030-national-environmental-policy--the-development-strategy-in-the-area-of-the-environment-and-water-management [accessed on: 16.04.2020]

COUNCIL OF MINISTERS OF POLAND (2019b), Mapa drogowa: Transformacji $w$ kierunku gospodarki o obiegu zamkniętym, https://www.gov.pl/web/rozwoj/rada-ministrow-przyjela-projekt-mapy-drogowej-goz [accessed on: 07.04.2020]

CZECH PRESIDENCY (2019), Programme for the Czech Presidency of the Visegrad Group 2019/2020, https://www.mzv.cz/file/3572188/programme_CZ_V4_PRES_2019_2020.pdf [accessed on: 16.04.2020]

DELOITTE (2018), Closed Loop - Open Opportunities. Circular economy in Poland, https://www2. deloitte.com/pl/en/pages/zarzadzania-procesami-i-strategiczne/articles/innowacje/raport-zamkniety-obieg-otwarte-mozliwosci.html [accessed on: 07.04.2020]

ELLEN MACARTHUR FOUNDATION (2014), CE 100. The world's leading circular economy network, https://www.ellenmacarthurfoundation.org/ce100/ [accessed on: 10.09.2017]

ELLEN MACARTHUR FOUNDATION (2014), Towards the Circular Economy: Accelerating the Scale-up Across Global Supply Chains, http://www3.weforum.org/docs/WEF_ENV_TowardsCircularEconomy_Report_2014.pdf [accessed on: 12.01.2018]

ENGELMAN, R. (2013), 'Beyond Sustainababble', [in:] State of the World 2013, Washington, DC, Island Press - Center for Resource Economics, pp. 3-16, https://link.springer.com/chapter/10.5 822\%2F978-1-61091-458-1_1/ [accessed on: 28.10.2018]

ERNST \& YOUNG ACCOUNTANTS LLP (2015), Are You Ready for the Circular Economy? The Necessity of an Integrated Approach, http://www.ey.com/Publication/vwLUAssets/EY-brochurecas-are-you-ready-for-the-circular-economy/\$FILE/EY-brochure-cas-are-you-ready-for-thecircular-economy.pdf/ [accessed on: 01.12.2017]

EUROPEAN COMMISSION (2011), Roadmap to a Resource Efficient Europe, COM/2011/0571 final, https://eur-lex.europa.eu/legal-content/EN/TXT/?uri=CELEX:52011DC0571 [accessed on: 18.04 .2020$]$

EUROPEAN COMMISSION (2014), General Union Environment Action Programme to 2020. Living Well, Within the Limits of Our Planet, Luxembourg: Publications Office of the European Union. https://op.europa.eu/en/publication-detail/-/publication/1d861dfb-ae0c-4638-83ab-69b234bde376 [accessed on: 12.04.2020]

EUROPEAN COMMISSION (2015), Closing the loop - an EU action plan for the circular economy, $\operatorname{COM}(2015) 0614$ final, https://eur-lex.europa.eu/legal-content/EN/TXT/?qid=1453384154337 \&uri=CELEX:52015DC0614 [accessed on: 16.04.2020]

EUROPEAN COMMISSION (2018a), A European Strategy for Plastics in a Circular Economy, $\operatorname{COM}(2018) 028$ final, https://eur-lex.europa.eu/legal-content/EN/TXT/?uri=COM\%3A2018\% 3A28\%3AFIN [accessed on: 16.04.2020]

EUROPEAN COMMISSION (2018b), Directive (EU) 2018/851 of the European Parliament and of the Council of 30 May 2018 amending Directive 2008/98/EC on waste, https://eur-lex.europa. eu/legal-content/EN/TXT/?uri=celex:32018L0851 [accessed on: 20.04.2020]

EUROPEAN COMMISSION (2018c), Measuring progress towards circular economy in the European Union - Key indicators for a monitoring framework, COM(2018) 29 final, https://ec.europa. eu/environment/circular-economy/pdf/monitoring-framework.pdf [accessed on: 20.04.2020]

EUROPEAN COMMISSION (2018d), The early warning report for Hungary, SWD(2018) 419 final, https://ec.europa.eu/environment/waste/pdf/early_warning_report_HU.pdf [accessed on: 26.04.2020] 
EUROPEAN COMMISSION (2018e), The early warning report for Slovakia, SWD(2018) 424

final, https://ec.europa.eu/environment/waste/pdf/early_warning_report_SK.pdf [accessed on: 26.04.2020]

EUROPEAN COMMISSION (2019a), The Environmental Implementation Review 2019. Country report Czech Republic, https://ec.europa.eu/environment/eir/pdf/report_cz_en.pdf [accessed on: 14.04.2020]

EUROPEAN COMMISSION (2019b), The Environmental Implementation Review 2019. Country report Hungary, https://ec.europa.eu/environment/eir/pdf/report_hu_en.pdf [accessed on: 15.04.2020]

EUROPEAN COMMISSION (2019c), The Environmental Implementation Review 2019. Country report Poland, https://ec.europa.eu/environment/eir/pdf/report_pl_en.pdf [accessed on: 16.04.2020]

EUROPEAN COMMISSION (2019d), The European Green Deal, COM(2019) 640 final, https:// ec.europa.eu/info/files/communication-european-green-deal_en [accessed on: 16.04.2020]

EUROPEAN COMMISSION (2020a), A New Industrial Strategy for Europe, COM(2020)102 final, https://ec.europa.eu/info/sites/info/files/communication-eu-industrial-strategy-march-2020 en.pdf [accessed on: 26.04.2020]

EUROPEAN COMMISSION (2020b), Circular Economy Action Plan: For a cleaner and more competitive Europe, https://ec.europa.eu/knowledge4policy/publication/communication-com202098-new-circular-economy-action-plan-cleaner-more-competitive-europe_en [accessed on: 16.04.2020]

EUROSTAT (2001), Economy-Wide Material Flow Accounts and Derived Indicators - A Methodological Guide, Luxembourg: Office for Official Publications of the European Communities. https://ec.europa.eu/eurostat/documents/1798247/6191533/3-Economy-wide-material-flow-accounts...-A-methodological-guide-2001-edition.pdf/ [accessed on: 10.03.2020]

EUROSTAT (2009), Economy-Wide Material Flow Accounts: Compilation Guidelines for Reporting to the 2009 Eurostat Questionnaire, Version 01, Luxembourg: Office for Official Publications of the European Communities. https:/unstats.un.org/unsd/envaccounting/ceea/ archive/Framework/Eurostat\%20MFA\%20compilation\%20guide_2009.pdf [accessed on: 10.03.2020]

EUROSTAT (2018), Economy-wide Material Flow Accounts (EW-MFA). Compilation Guide 2018, Luxembourg: Office for Official Publications of the European Communities. https://ec.europa. eu/eurostat/documents/3859598/9117556/KS-GQ-18-006-EN-N.pdf/b621b8ce-2792-47ff9d10-067d2b8aac4b [accessed on: 28.03.2020]

FLYNN, A., HACKING, N. and XIE, L. (2019), 'Governance of the circular economy: A comparative examination of the use of standards by China and the United Kingdom', Environmental Innovation and Societal Transitions, 33, pp. 282-300. https://doi.org/10.1016/j.eist.2019.08.002 [accessed on: 28.03.2020]

GHISELliNI, P., CIALANI, C. and ULGIATI, S. (2016), 'A Review on Circular Economy: The Expected Transition to a Balanced Interplay of Environmental and Economic Systems', Journal of Cleaner Production, 114, pp. 11-32. https://doi.org/10.1016/j.jclepro.2015.09.007 [accessed on: 08.04.2020]

GOVERNMENT OF HUNGARY (2011), Nemzeti Környezettechnológiai Innovációs Stratégia, Magyar Közlöny: No 103. 28147-28221 [https://docplayer.hu/7044622-A-kormany-1307-2011-ix-6-korm-hatarozata-a-nemzeti-kornyezettechnologiai-innovacios-strategiarol. $\mathrm{html}]$

GOVERNMENT OF HUNGARY (2013), Országos Hulladékgazdálkodási Terv 2014-2020', https:/eionet.kormany.hu/download/f/16/71000/Orszagos\%20Hulladekgazdalkodasi\%20 Terv\%202014-2020.pdf [accessed on: 30.03.2020] 
GRDIĆ, Z.S., NIŽIĆ, M.K. and RUDAN, E. (2020), 'Circular Economy Concept in the Context of Economic Development in EU Countries', Sustainability, 12, 3060. https://doi.org/10.3390/ su12073060 [accessed on: 26.06.2020]

HUNGARIAN PARLIAMENT (2015), Nemzeti Környezetvédelmi Program 2015-2020, https://net.jogtar.hu/getpdf?docid=A15H0027.OGY\&targetdate $=\&$ printTitle $=27 / 2015 .+\%$ 28VI.+17.\%29+OGY+hat\%C3\%A1 rozat\&getdoc=1 [accessed on: 30.03.2020]

INTERNATIONAL RESOURCE PANEL (2019), Global Resource Outlook 2019: Natural Resources for the Future We Want, United Nations Environment Programme, Nairobi, https://wedocs. unep.org/handle/20.500.11822/27517 [accessed on: 26.06.2020]

KIRCHHERR, J., REIKE, D. and HEKKERT, M. (2017), 'Conceptualizing the circular economy: An analysis of 114 definitions', Resources, Conservation and Recycling, 127, pp. 221-232. https://doi.org/10.1016/j.resconrec.2017.09.005 [accessed on: 19.06.2020]

MINISTERSTWO ŚRODOWISKA (2019), Polityka Surowcowa Państwa, http://psp.mos.gov.pl/ images/pdf/PSP_projekt.pdf [accessed on: 01.07.2020]

MINISTERSTVO ŽIVOTNÉHO PROSTREDIA SR (2019), Zelenšie Slovensko - Stratégia environmentálnej politiky Slovenskej republiky do roku 2030 Zelenšie Slovensko, Enviro portal, https://www.enviroportal.sk/clanok/zelensie-slovensko-strategia-environmentalnej-politiky-slovenskej-republiky-do-roku-2030 [accessed on: 16.04.2020]

MINISTERSTVO ŽIVOTNIHO PROSTŔEDI (2020), Česká Republika 2030, https://www.cr2030. cz [accessed on: 05.04.2020]

MINISTRY OF THE ENVIRONMENT OF THE CZECH REPUBLIC (2012), State Environmental Policy 2012-2020. Updated version 2016, https://www.mzp.cz/C125750E003B698B/en/sep cz/\$FILE/SOPSZP-SEP2012-2020(2016)-170404.pdf [accessed on: 05.04.2020]

MINISTRY OF THE ENVIRONMENT OF THE CZECH REPUBLIC (2014), Waste Management Plan of the Czech Republic for the Period 2015-2024, https://www.mzp.cz/C1257458002F0DC7/cz/plan_odpadoveho_hospodarstvi_aj/\$FILE/OODP-WMP_CZ_translation-20151008. pdf [accessed on: 13.04.2020]

MOMETE, D.C. (2020), 'A unified framework for assessing the readiness of European Union economies to migrate to a circular modelling', Science of The Total Environment, 718, 137375. https://doi.org/10.1016/j.scitotenv.2020.137375 [accessed on: 19.06.2020]

MURRAY, A., SKENE, K. and HAYNES, K. (2017), 'The Circular Economy: An Interdisciplinary Exploration of the Concept and Application in a Global Context', Journal of Business Ethics, 140 (3), pp. 369-380, http://link.springer.com/10.1007/s10551-015-2693-2 [accessed on: 20.04.2020]

NATIONAL SUSTAINABLE DEVELOPMENT COUNCIL OF HUNGARY (2013), Nemzeti Fenntartható Fejlödési Keretstratégia 2013, Budapest: Nemzeti Fenntartható Fejlődési Tanács. https://www.nfft.hu/documents/1238941/4101589/Nemzeti+Fenntarthat\%C3\%B3+Fej1\%C 5\%91d\%C3\%A9si+Keretstrat\%C3\%A9gia.pdf/4ee5e 5a 1-4bbc-4433-8245dd2f52a4e667? $\mathrm{t}=1580132846319$ [accessed on: 30.03.2020]

NAUDÉ, M. (2011), 'Sustainable Development in Companies: Theoretical Dream or Implementable Reality?', Corporate Ownership \& Control Journal, 8 (4), pp. 352-364. https://doi. org/10.22495/cocv8i4c3art4

OECD (2011), Towards Green Growth, Paris: OECD Publishing, https:/www.oecd.org/greengrowth/48012345.pdf [accessed on: 10.04.2020].

OECD (2016), Policy Guidance on Resource Efficiency, Paris: OECD Publishing, https://www. oecd.org/env/policy-guidance-on-resource-efficiency-9789264257344-en.htm [accessed on: 08.04.2020]

OECD (2017), Making the Slovak Republic a More Resource Efficient Economy, Paris: OECD Publishing, https://www.oecd.org/environment/waste/Policy-Paper-Making-the-Slovak-Republic-a-more-resource-efficient-economy.pdf [accessed on: 20.04.2020] 
OECD (2018a), Environmental Performance Reviews: Czech Republic 2018, Paris: OECD Publishing, https://www.oecd.org/env/czech-republic-2018-9789264300958-en.htm [accessed on: 21.04.2020]

OECD (2018b), Environmental Performance Reviews: Hungary 2018, Paris: OECD Publishing, https://www.oecd.org/publications/hungary-2018-9789264298613-en.htm [accessed on: 21.04.2020]

OECD (2019), Waste Management and the Circular Economy in Selected OECD Countries: Evidence from Environmental Performance Reviews, OECD Environmental Performance Reviews: Paris. OECD Publishing. https://doi.org/10.1787/9789264309395-en

OFFICE OF THE GOVERNMENT OF THE CZECH REPUBLIC - Government Council for Sustainable Development (2017), National Report on the Implementation of the 2030 Agenda for Sustainable Development, https:/www.vlada.cz/assets/ppov/udrzitelny-rozvoj/dokumenty/ CZE-VNR-to-HLPF_2017_National-Report.pdf [accessed on: 05.04.2020]

POLISH PRESIDENCY (2020), 2020/2021 Polish Presidency: Back on Track, http://www.visegradgroup.eu/documents/presidency-programs/2020-2021-polish [accessed on: 01.07.2020]

SASSANELLI, C., ROSA, P., ROCCA., R. and TERZI, S. (2019), 'Circular economy performance assessment methods: A systematic literature review', Journal of Cleaner Production, 229, pp. 440-453. https://doi.org/10.1016/j.jclepro.2019.05.019 [accessed on: 20.04.2020]

ŠVECOVÁ, L., OSTAPENKO, G. and VEBER, J. (2019), 'Circular Economy in the Czech Republic', Proceedings of the 2nd International Conference on Education Science and Social Development (ESSD 2019), pp. 551-554. https://doi.org/10.2991/essd-19.2019.122, [accessed on: 22.04.2020]

VISEGRAD GROUP PRESIDENCY PROGRAMMES (2018), http://www.visegradgroup.eu/documents/presidency-programs [accessed on: 16.04.2020]

UNITED NATIONS (1987), Report of the World Commission on Environment and Development Our Common Future, http://www.un-documents.net/wced-ocf.htm: [accessed on: 28.10.2018]

UNITED NATIONS ENVIRONMENT PROGRAMME (2011), Towards a Green Economy: Pathways to Sustainable Development and Poverty Eradication. A Synthesis for Policy Makers, Nairobi: UNEP, https://sustainabledevelopment.un.org/content/documents/126GER_synthesis_en.pdf [accessed on: 22.04.2020]

ZIELIŃSKA, A. (2019), 'Comparative Analysis of Circular Economy Implementation in Poland and other European Union Countries', Journal of International Studies, 12 (4), pp. 337-347. https://doi.org/10.14254/2071-8330.2019/12-4/22 [accessed on: 20.04.2020] 